\title{
Developing Higher-Order Thinking Skill (HOTS) Problem in Algebra Form Materials in State Junior High School 1 Mataram
}

\author{
Nyoman Sridana* \\ Mathematics Education Study Program \\ Universitas Mataram \\ Mataram, Indonesia \\ sridana60@gmail.com
}

\author{
Sudi Prayitno \\ Mathematics Education Study Program \\ Universitas Mataram \\ Mataram, Indonesia
}

\author{
Baidowi Baidowi \\ Mathematics Education Study Program \\ Universitas Mataram \\ Mataram, Indonesia
}

\begin{abstract}
This study aims to produce standard Higher-Order Thinking Skills (HOTS) evaluation tools on algebra materials. HOTS criteria are based on Bloom's Revised Cognitive Domain. The subjects of this study were seventh grade junior high school students in the odd semester of the academic year 2019/2020 at State Junior High School 1 Mataram, which was a model school for junior high schools in the city of Mataram. This research classified as research and development (R\&D) using a 3-D development model. The data collection technique used is a test. The validity of the questions was measured based on the assessment of expert validators, taking into account three aspects namely, content, suitability of the questions with Basic Competency (BC) and Grade Point Average (GPA); construct which is the suitability of the problem with the characteristics of HOTS; and language which the use of appropriate language (according to Indonesian spelling rules). The results of this study indicate that evaluation tools in the form of HOTS-standard questions on algebraic materials are valid and practical. Then, the model school can disseminate the results of the research to the impact school to be used as a reference in making similar teaching and learning's questions or in other materials.
\end{abstract} HOTS

Keywords - Bloom's Revised Cognitive Domain, algebra,

\section{INTRODUCTION}

Education in the industrial era 4.0 has various issues related to the progress of science and technology, it certainly has its own challenges as a $21^{\text {st }}$ century society. With the various advances that exist, competition in both the national and international area will be increasing rapidly. Therefore, everyone is required to master a variety of $21^{\text {st }}$ century skills, to prepare themselves to face increasing competition. $21^{\text {st }}$ century skills emphasize on four main things or better known as $4 \mathrm{C}$, such as critical thinking, creativity, communication, and collaboration[1].

One of the government's efforts in facing the challenges above is through the development and innovation of the 2013 curriculum. Changes continue to be made to relevant developments that occur in today's world [2]. Currently, the 2013 curriculum is designed to be in line with international education standards so that various improvements are made. In the content standard, a reduction in irrelevant material is then given a deepening and expansion of relevant material and enriched with the students' need to think critically and analytically according to international standards. In addition, assessment standards, gradually adapted international standard assessment models. Assessment of learning outcomes is expected to help students to improve higher order thinking skills (Higher Order Thinking Skills/HOTS), because higher level thinking skills can encourage students to think broadly and deeply about subject matter [3].

Development of learning and assessment oriented to higher order thinking skills or Higher Order Thinking Skills (HOTS) is a program that was developed as an effort to improve the quality of learning and improve the quality of graduates. Indonesian government hopes that through learning and assessment based on HOTS can help students in mastering $21^{\text {st }}$ century skills[4]. Therefore, teachers should begin to apply HOTS-based learning and the questions developed are expected to encourage the improvement of higher-order thinking skills, increase creativity, and build student independence to solve problems.

\section{METHOD}

This research classified as research and development (R\&D). The subjects in this study were 15 students at state Junior High School 1 Mataram in the academic year 2019/2020. The main stages in this study were:
a. Analysis phase
b. The design stage
c. Development and evaluation stage

\section{RESULTS AND DISCUSSION}

\section{A. Validity}

TABLE 1. VALIDITY RESULT

\begin{tabular}{|c|c|c|c|}
\hline No. & t value & t table & Category \\
\hline 1 & 4.380 & 1.771 & Valid \\
\hline 2 & 3.757 & 1.771 & Valid \\
\hline 3 & 6.406 & 1.771 & Valid \\
\hline 4 & 4.001 & 1.771 & Valid \\
\hline 5 & 4.579 & 1.771 & Valid \\
\hline 6 & 0.392 & 1.771 & invalid \\
\hline
\end{tabular}

\section{B. Reliability}

The reliability tests were calculated using the alpha formula. Obtained a value (r11) of 0.777 with the reliable category. 


\section{Difficulty level}

TABLE 2. DIFFICULTY LEVEL RESULT

\begin{tabular}{|c|c|c|}
\hline No. & Distinguishing power & Category \\
\hline 1 & 0.2 & Difficult \\
\hline 2 & 0.08 & Difficult \\
\hline 3 & 0.13 & Difficult \\
\hline 4 & 0.012 & Difficult \\
\hline 5 & 0.02 & Difficult \\
\hline 6 & 0 & Difficult \\
\hline
\end{tabular}

\section{Distinguishing power}

TABLE 3. DISTINGUISHING POWER RESULT

\begin{tabular}{|c|c|c|}
\hline No. & Distinguishing power & Category \\
\hline 1 & 0.27 & Sufficient \\
\hline 2 & 0.13 & Poor \\
\hline 3 & 0.27 & Sufficient \\
\hline 4 & 0.06 & Poor \\
\hline 5 & 0.04 & Poor \\
\hline 6 & 0 & Very Poor \\
\hline
\end{tabular}

The main purpose of this study was to produce HOTS questions on valid and reliable algebra form material with a proper index of difficulty and differentiation. From the tables above, it is known that from the six questions created only five were categorized as valid questions. As for the reliability of the questions amounted to 0.777 with very reliable criteria. However, the differentiation and difficulty index did not meet the expected criteria in this study. According to[5], good items are items that have the distinction of 0.4 to 0.7 and the difficulty index ranges from 0.3 to 0.7 . Thus, it can be concluded that the questions made need to be revised.

In this study, before students answer these questions they are given treatment in the form of teaching materials and students worksheets in the form of algebra to help them understanding the concepts of algebra forms. Based on the results of interviews with two mathematics teachers in class VII, according to them the level was very high for grade VII students. At the time, the research was also carried out on algebra material, students were just start to study, so that there are lack of concepts which need to be answered. In addition, according to the teacher, HOTS questions are rarely accustomed to students due to the various level of student ability, therefore, for the basic material, there are still many students who do not understand. Based on the teacher's suggestion, for the revision of the problem it is endeavored to make the question not too long because it leads to students' misconceptions of the questions. From the sudents' side, interviews with students indicated that the problem was indeed difficult and they had never solved a problem with that level before. However they thought the question was very challenging and very curious about how to solve the problem.

\section{CONCLUSION}

Based on the results and discussion, it can be concluded that: (1) of the six questions developed only five are categorized as valid; (2) the difficulty index and distinguishing power of the questions still do not meet the good criteria, so it is necessary to revise the questions; and (3) based on the results of interviews with students, it can be illustrated that the problem has the potential effect of being able to attract interest, seriousness and motivation of students in solving the problems.

\section{REFERENCES}

[1] "Skills for 21st Century: what should students learn," Central Curriculum Redesign. 2015, [Online]. Available: www.curriculumredesign.org.

[2] Kunandar, Penilaian Autentik. Jakarata: PT Gafindo Persada, 2013.

[3] I. W. Widana, Penyusunan Soal Keterampilan Tingkat Tinggi Matematika. Jakarta: Ditjen Pendidikan Dasar dan Menengah, 2018.

[4] I. W. Widana, Penyusunan Soal Higher Order Thinking Skill (HOTS). Jakarta: Ditjen Pendidikan Dasar dan Menengah, 2017.

[5] S. Arikunto, Dasar - Dasar Evaluasi Pendidikan Edisi 2. Jakarta: Bumi Aksara, 2016. 